\title{
Performance analysis of solar water heater in NEH region of India
}

\author{
Mahendra S. Seveda \\ Department of Farm Power and Machinery, College of Agricultural Engineering and Post Harvest Technology, Central Agricultural \\ University, Ranipool, Gangtok, Sikkim-737135, India
}

\section{Email address:}

sevda_mahendra@rediffmail.com

\section{To cite this article:}

Mahendra S. Seveda. Performance Analysis of Solar Water Heater in NEH Region of India. International Journal of Renewable and Sustainable Energy. Vol. 2, No. 3, 2013, pp. 93-98, doi: 10.11648/j.ijrse.20130203.13

\begin{abstract}
In the present study, a natural circulation closed thermosyphon flat plate solar water heater has been tested at the College of Agricultural Engineering and Post Harvest Technology, Central Agricultural University, Ranipool, (27 ${ }^{\circ}$, $88^{\circ} \mathrm{E}$ ), Gangtok, Sikkim, India. Data were collected for several sunny and cloudy days. Dynamic response of the system to variations in solar insolation was studied and analyzed. Maximum water temperature obtained was the $75^{\circ} \mathrm{C}$ while the maximum ambient temperature was $21^{\circ} \mathrm{C}$. The performance of the system can be improved by using working fluid as glycol. Glycol as working fluid can be considered for substituting water in the flat plate collector in view of the fact that the fluid has low boiling point coupled with high latent heat.
\end{abstract}

Keywords: Solar Water Heater, Thermosyphon, Solar Insolation, Flat Plate Collector

\section{Introduction}

Water heating typically represents a high percentage of energy consumption in homes and businesses, in some cases $30 \%$ or more [1]. When solar water heating systems supplement or replace conventional water heaters they displace some or all of the fuel that would have been used in those systems. While carbon intensity of baseline fuels for water heating varies, it is generally high in many locations. Consequently, emissions of greenhouse gases and other pollutants are reduced, helping to mitigate climate change while often improving local air quality, and sometimes indoor air quality as well [2]. Due to the increasing prices of the primary energy resources and their associated serious environmental issues, the use of renewable resources, especially, the solar energy is increasingly on demand in both developing and developed countries [3]. Solar energy is one of the best sources of energy for water heating. Hot water is required for domestic and industrial uses such as houses, hotels, hospitals, and mass-production and service industries [4].

A closed-loop system uses a heat-transfer fluid (water or diluted antifreeze) to collect heat and a heat exchanger (usually of mantle type) to transfer the heat to domestic water supply. A disadvantage of closed looped system is that heat is lost during the heat exchange process [5].
Sitzmann recommended utilization of such systems and provided basic information to manufacture and use closed-loop systems. Solar water heating system is also characterized as active or passive [6]. An active system uses an electric pump to circulate the fluid through the collector. A passive system moves supply water or a heat-transfer fluid through the system without any pumps and relies on thermosyphoning to circulate water. This phenomenon is often made use of in the design of solar water heaters, particularly of small capacities. In these systems, heat transfer fluid rises up from the solar energy collector to the hot water store due to the action of buoyancy forces and is replaced by colder water from the bottom of the tank [7]. A continuous circulation is thus established between the collectors to the tank which helps in heating up water in the storage tank.

Thermosyphon solar water heaters still remain, many decades since their first appearance, one of the most interesting technologies for exploitation of solar energy. Their remarkable efficiencies, combined with simplicity of construction, autonomy in operation, absence of moving parts and thus the minimization of necessary maintenance, make them an attractive alternative to pumped solar systems [8].

The thermal performance of thermosyphon flat-plate solar water heater with a mantle heat exchanger was 
investigated to show its applicability in China. The effect on the performance of the collector of using a heat exchanger between the collector and the tank was analyzed. A "heat exchanger penalty factor" for the system was determined and energy balance equation in the system was presented. Outdoor tests of thermal performance of the thermosyphon flat-plate solar water heater with a mantle heat exchanger were taken in Kunming, China. Experimental results show that mean daily efficiency of the thermosyphon flat plate solar water heater with a mantle heat exchanger with $10 \mathrm{~mm}$ gap can reach up to $50 \%$, which is lower than that of a thermosyphon flat-plate solar water heater without heat exchanger, but higher than that of a all-glass evacuated tubular solar water heater [8].

The most commonly used solar water heating system for domestic needs is through natural circulation type that consists of a flat plate solar collector connected to an insulated storage tank. The sun's rays pass through the glass and are trapped in the space between the cover and plate or are absorbed by the black body [9]. The circulating water through a conduit system located between the cover and absorber plate is heated and then carried to the storage tank. Flat plate collectors are most suitable when a temperature below $100 \mathrm{oC}$ is required. These are simple to assemble; low cost; simple in design and fabrication; durable; do not require sun-tracking; can work on cloudy days; and require minimum maintenance. The performance of the thermosyphon system depends upon the size and capacity of the storage tank, the thermal capacity of the collector and the connecting pipes including fluid flow and on the pattern of hot water use [10].

A solar flat plate collector of fixed orientation was fabricated and connected to a heat exchanger, which was kept inside the water storage drum. The developed collector was a low temperature device operating with the temperature range of ambient to $100^{\circ} \mathrm{C}$. Acetone was selected as an alternative working fluid and allowed to re circulate in a closed loop. A shell and tube type heat exchanger (non-mixing) was designed and fabricated for the heat transfer between acetone and water.

The solar intensity increased from $55 \mathrm{mw} / \mathrm{cm} 2$ at 8.30 am to $85 \mathrm{mw} / \mathrm{cm} 2$ at $1.30 \mathrm{pm}$ and decreased to $64 \mathrm{mw} / \mathrm{cm} 2$ at $5.00 \mathrm{pm}$. The absorber plate temperature, which remained nearly constant for the first two hours, went up to $90^{\circ} \mathrm{C}$ in the next two hours. It was nearly constant from 11.00 am to $1.30 \mathrm{pm}$ and then dropped down to $72^{\circ} \mathrm{C}$ in the afternoon. The hot fluid was found to loose heat to the surrounding water at more or less constant rate from 11.30 am to $5.00 \mathrm{pm}$. The highest temperature of acetone $\left(70^{\circ} \mathrm{C}\right)$ was observed during $1.00 \mathrm{pm}$ to $2.00 \mathrm{pm}$. The temperature of water increased from $30^{\circ} \mathrm{C}$ to a maximum of $62^{\circ} \mathrm{C}$. Overall efficiency of the system was found to be $45 \%$ while considering the solar input to the heat gained by the water. Alternative working fluids such as acetone, methanol or ethanol may be considered for substituting water in the flat plate collector in view of the fact that the fluids have low boiling point coupled with high latent heat of evaporation
[11].

\section{Experimental Set-up}

The tests were conducted at the roof top of the Hon'ble Vice Chancellor's Annexe, College of Agricultural Engineering and Post Harvest Technology, Central Agricultural University, Ranipool $\left(27^{\circ} \mathrm{N}, 88^{\circ} \mathrm{E}\right)$, Gangtok, Sikkim, India. The schematic diagram of the thermosyphon flat plate solar water heating system is shown in Fig 1. The closed view of the thermosyphon flat plate solar water heating system is shown in Fig 2. The system consists of five flat plate collectors, storage tank and connecting pipes. The flat plate collectors are oriented in south direction that it receives maximum solar radiation. The detail technical specifications of solar water heating system are given in Table 1.

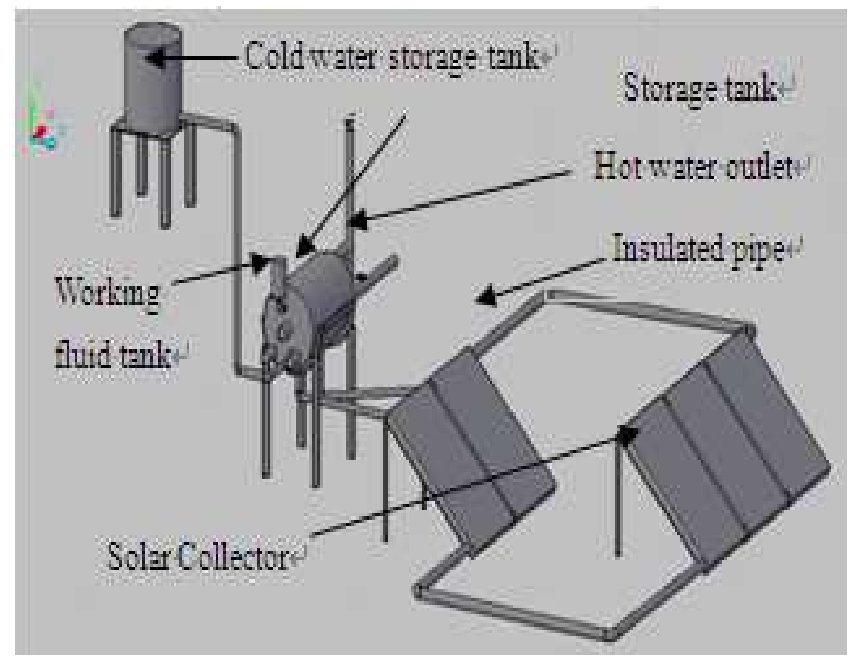

Figure 1. Schematic diagram of solar water heating system

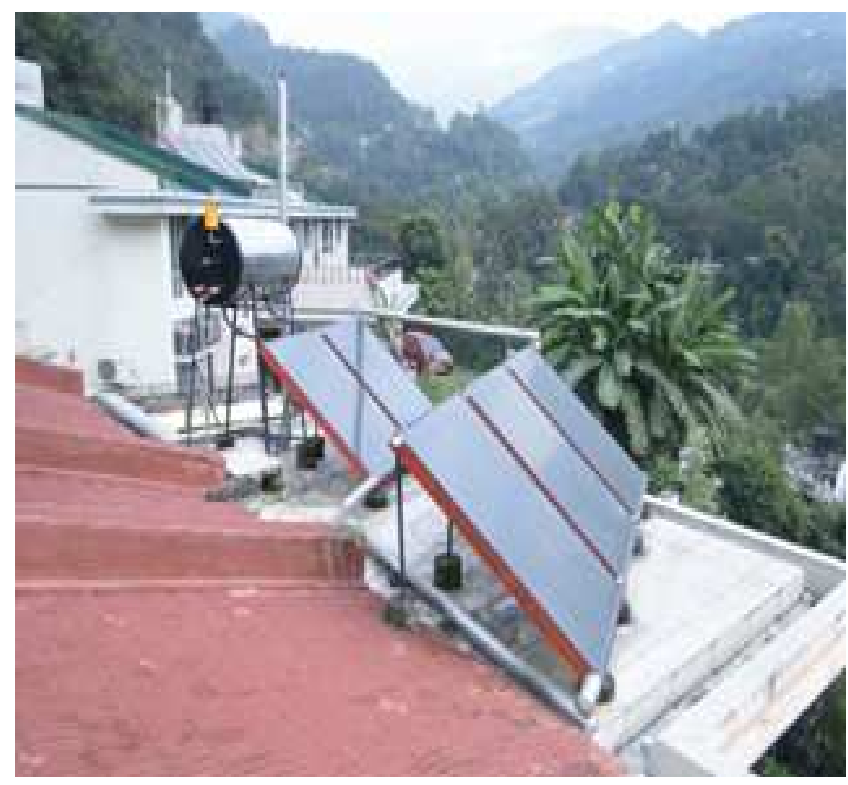

Figure 2. Closed view of thermosyphon type solar water heating system 
Table 1. Specification of the system tested in the study

\begin{tabular}{ll}
\hline System Parts & Specification \\
\hline 1. Collector & Flat plate (5 Nos.) \\
Type & $38^{\circ}$, Facing south \\
Tilt angle & $180 \times 120 \mathrm{~cm}$ \\
Absorber area & $10 \mathrm{~cm}$ \\
Absorber plate thickness & $0.4 \mathrm{~cm}$ \\
Glass cover thickness & 10 \\
No. of risers & Aluminum \\
Frame & \\
2. Storage tank & Horizontal \\
Type & Galvanized iron \\
Material & $130.6 \mathrm{~cm}$ \\
Length & $80 \mathrm{~cm}$ \\
Diameter & 500 Litres \\
Capacity & Glass wool \\
Insulation & \\
3. Cold water storage tank & PVC \\
Material & 500 Litres \\
Volume & \\
4. Inlet pipe & Galvanized iron \\
Material & $3.2 \mathrm{~cm}$ \\
Diameter & \\
5. Outlet pipe & Galvanized iron \\
Material & $2.16 \mathrm{~cm}$ \\
Diameter & Glass wool \\
Insulation & $3.77 \mathrm{~cm}$ \\
Thickness of insulation & 27 Liters \\
6. Working fluid capacity &
\end{tabular}

\section{Basic Components of Solar Water Heating System}

\subsection{Solar Collector}

The solar collector is the key component of the solar water heating system. Its design is the single most influential aspect of the system performance, both thermally and economically. It absorbs the solar radiation and converts it into a useable form of energy that can be applied to meet a specific demand. It collects the solar radiation and heated up the working fluid. A typical flat-plate collector consists of an absorber, transparent cover sheets and an insulated box. The absorber is usually a sheet of high-thermal conductivity metal with tubes or ducts either integral or attached. Its surface is painted or coated to maximize radiant energy absorption and in some cases to minimize radiant emission. The insulated box provides structure and sealing and reduces heat loss from the back or sides of the collector.

\subsection{Storage Tank}

The storage tank used in the study is horizontal type with the capacity of 500 litres. The heat exchange between the heated working fluid and cold water occurred in the storage tank. It is insulated to reduce heat loss during cloudy day and night time.

\subsection{Cold Water Storage Tank}

A cold water storage tank of 500 litres capacity was used in the study which is connected to the city water supply. It is made up of PVC (polyvinyl chloride).

\subsection{Piping System}

\subsubsection{Inlet Pipe}

It is made up of Galvanized iron with diameter of $3.2 \mathrm{~cm}$. It supplied water to the storage tank from the cold water storage tank.

\subsubsection{Outlet Pipe}

It is also made up of Galvanized iron with diameter of $2.16 \mathrm{~cm}$. It is insulated with glass wool. It is connected to the Storage tank and to the solar collectors and drawn out the heated water.

\section{Selection of Working Fluid}

The working medium for the flat plate collector was selected based on the following desirable properties [11]:

I Low boiling point

II High specific heat

III High latent heat

IV Non-corrosiveness for most of the fabrication materials

$\mathrm{V}$ Wide useful range

VI Easily available in the market and low in cost

VII Excellent stability in the working range

VIII Low freezing temperature

IX Should not form scales in the tubes

$\mathrm{X}$ High thermal conductivity

Generally, water is used as a working fluid for a solar flat plate collector. There are two type of working fluids were selected e.g. water and ethylene glycol.

\section{Testing Method and Performance Evaluation}

The storage was filled with 500 litres of water and working fluid tubes were filled with working fluid through the working fluid tank. The working fluid is supplied from the working tank which flows inside the tubes in the collectors and then to the solar water storage tank. A part of incidence solar radiation on the glass cover is reflected back to atmosphere and remaining is transmitted inside the solar collectors and the solar radiation is absorbed by the working fluid.

Due to the absorption of solar radiation, working fluid temperature increases and the working fluid starts emitting long wavelength radiation which is not allowed to escape to atmosphere due to presence of glass cover. Thus the temperature above the working fluid inside the solar collectors becomes higher. The insulation provided at the bottom and all the sides of solar collectors and glass cover 
serves the purpose of reducing direct convective losses to the ambient which further becomes beneficial for rise in working fluid and solar collectors temperature respectively. The heated working fluid moves upward due to decrease in density whereas the colder working fluid settled at the lower portion due to more in density. The heat from the working fluid is transferred to the water and thus the water is heated up, this process is taking place in storage tank. The hot water is collected from the outlet which is connected to the solar water storage tank. Cold water temperature $(\mathrm{oC})$, working fluid temperature $(\mathrm{oC})$, solar collector temperature $(\mathrm{oC})$, storage tank temperature $(\mathrm{oC})$, solar insolation $(\mathrm{W} / \mathrm{m} 2)$, ambient temperature $(\mathrm{oC})$, wind velocity $(\mathrm{m} / \mathrm{sec}$.), hot water temperature $(\mathrm{oC})$ and relative humidity $(\%)$ were recorded at 30-minute intervals. Figure 3. Shows recording the data of surface temperature of collector with help of infrared thermometer.



Figure 3. Measurement of surface temperature of solar collector

\section{Efficiency Calculation}

The efficiency of the flat plate collector with an alternative working fluid was calculated using the heat gained by water with respect to the actual solar energy received by the flat plate collector (Eqn. 1) [11].

Overall efficiency of the system $=$ (heat gained by water/input solar energy)

Heat gained by the water $=\mathrm{m} \mathrm{c}_{\mathrm{p}} \Delta \mathrm{T}$

Input solar energy (solar energy falling on the collector)

$=\mathrm{qAT}$

Where,

$\mathrm{m}=$ weight of water (gram)

$\mathrm{cp}=$ specific heat of water (joule/gram oC)

$\Delta \mathrm{T}=$ temperature difference (outlet temperature-inlet temperature, oC)

$\mathrm{q}=$ solar insolation (joule/ hour. $\mathrm{m} 2$ )

$\mathrm{A}=$ area of the collector $(\mathrm{m} 2)$

$\mathrm{T}=$ time (hour)

\section{Instrumentation and Experiments}

The tests were conducted from 07.00 to $19.00 \mathrm{~h}$ including both sunny day and cloudy day and the one hour interval data were recorded in the month of November, 2011 using water and ethylene glycol as a working fluid. Cold water temperature was measured in the cold water storage tank with the help of Digital thermometer, its unit is in ${ }^{\circ} \mathrm{C}$. Working fluid temperature measurement was taken in working fluid tank with the help of digital thermometer, its unit taken ${ }^{\circ} \mathrm{C}$. Collector temperature was recorded at the upper surface of the glazing of the solar collector with the help of infra red thermometer. It is measured in ${ }^{\circ} \mathrm{C}$.

Storage tank temperature reading was taken in the temperature guage which is attached to the side of the solar water storage tank. It is measured in ${ }^{\circ} \mathrm{C}$. The amount of solar radiation falling to the surface of solar collector was measured with the help of Luxmeter. Its unit is on Lux. The ambient temperature during the experiment was measured with the instrument called digital thermometer, the readings were in ${ }^{\circ} \mathrm{C}$. The hot water output temperature was taken inside the bathroom with the help of Digital thermometer. Its unit is in ${ }^{\circ} \mathrm{C}$.

\section{Results and Discussion}

The thermosyphon flat plate solar water heating system was tested in NEH region of India. The thermal performance of Thermosyphon flat plate solar water heating system was investigated and compared using ethylene glycol and water as a working fluid on both sunny day and cloudy day. The tests were conducted from 07.00 to $19.00 \mathrm{hrs}$ with the time interval of 30 minute in the month of November, 2011 and the data was recorded. This shows that the hot water temperature was $75^{\circ} \mathrm{C}(257 \%)$ higher than the ambient temperature. The result obtained shows that the water temperature in the system is a function of solar radiation and the ambient air. A typical day analysis of the system shows that the collector efficiency is higher especially around mid day when the solar collector receives the highest energy.

Experiments were conducted for several days of November, 2011. To study the temperature and flow distribution in the system during its daily operation, experiments were conducted by filling the storage tank with cold water every morning. The period of testing for each run was from 7 a. m. to 19 p. m. and during the tests, no water was withdrawn from the storage.

\subsection{Variation of Temperature}

It was observed that the initial water temperature, storage tank temperature and hot water output temperature was $15^{\circ} \mathrm{C}, 52^{\circ} \mathrm{C}$ and $46^{\circ} \mathrm{C}$ respectively in the month of November, 2011at 7:00 hrs using water as working fluid. It was found that the temperature gradually increased and at 13:00-14:00 hrs attained the maximum temperature of $23^{\circ} \mathrm{C}$, 
$69^{\circ} \mathrm{C}$ and $62^{\circ} \mathrm{C}$ respectively and the temperature started gradually decreased towards the evening and at 19:00 hrs it was found to be $20^{\circ} \mathrm{C}, 61^{\circ} \mathrm{C}$ and $53^{\circ} \mathrm{C}$ respectively. The trend of results is plotted on graph as shown in Fig. 4.

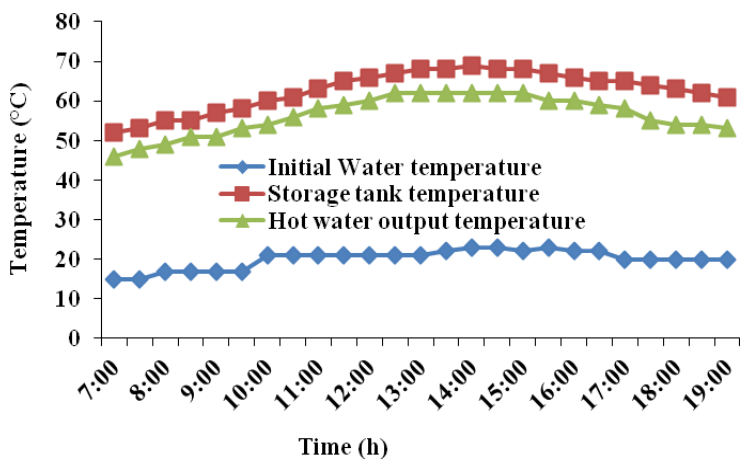

Figure 4. Time variation of initial water temperature, storage tank temperature and hot water output temperature using water as a working fluid on a sunny day

Figure 5 shows a typical day in the month of November, 2011at 7:00 hrs results of the hourly variation of the temperatures using ethylene glycol as a working fluid, the initial water temperature, storage tank temperature and hot water output temperature was $16^{\circ} \mathrm{C}, 60^{\circ} \mathrm{C}$ and $57^{\circ} \mathrm{C}$ respectively. And temperatures found to be highest at 13:00 to $14: 00 \mathrm{hrs} 22^{\circ} \mathrm{C}, 75^{\circ} \mathrm{C}$ and $71^{\circ} \mathrm{C}$ respectively and then gradually decreased towards the evening at 19:00 hrs recorded $18^{\circ} \mathrm{C}, 68^{\circ} \mathrm{C}$ and $59^{\circ} \mathrm{C}$ respectively.



Figure 5. Time variation of initial water temperature, storage tank temperature and hot water output temperature using ethylene glycol as a working fluid on a sunny day

\subsection{Variation of Solar Insolation}

The maximum temperature on the absorber plate occurs at $14: 00$ when it reaches $48^{\circ} \mathrm{C}$. On this day the maximum incident energy on the plane of the absorber is $905 \mathrm{~W} / \mathrm{m}^{2}$ which only lasts for a short period of time. After 13:00, although incident radiation starts dropping, the absorber temperature continues rising for two more hours. The curve labeled by the letter $\mathrm{S}$ in Fig. 6, represents the measured solar insolation.

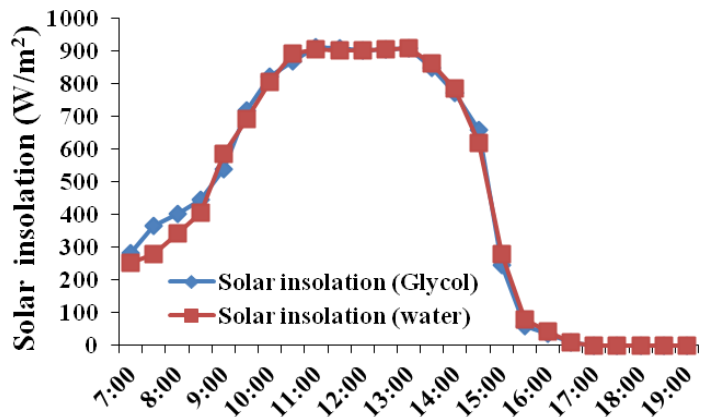

Time (h)

Figure 6. Time variation of solar insolation during the experiment using glycol and water as a working fluid on a sunny day

The curve labelled by the letter S in Fig. 7, represents the measured solar insolation. The solar collector efficiency using water and ethylene glycol as a working fluid on a sunny day in the month of November, 2011, was $60 \%$ and $51.3 \%$ respectively.

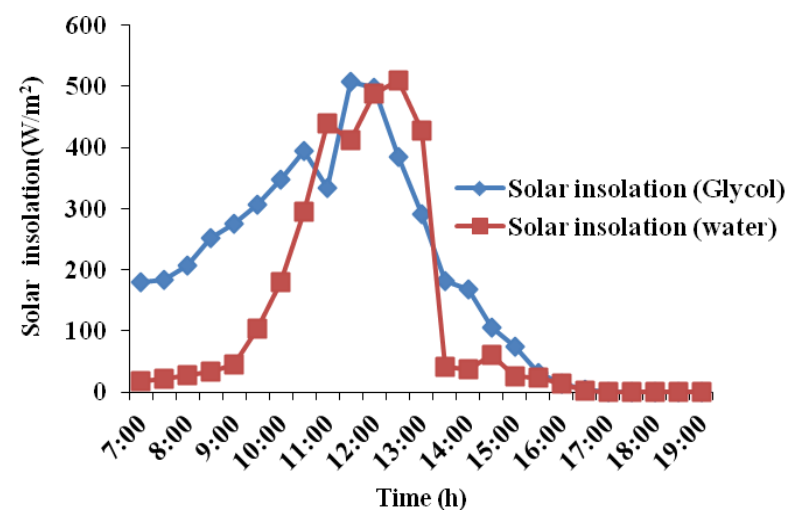

Figure 7. Time variation of solar insolation during the experiment using glycol and water as a working fluid on a cloudy day

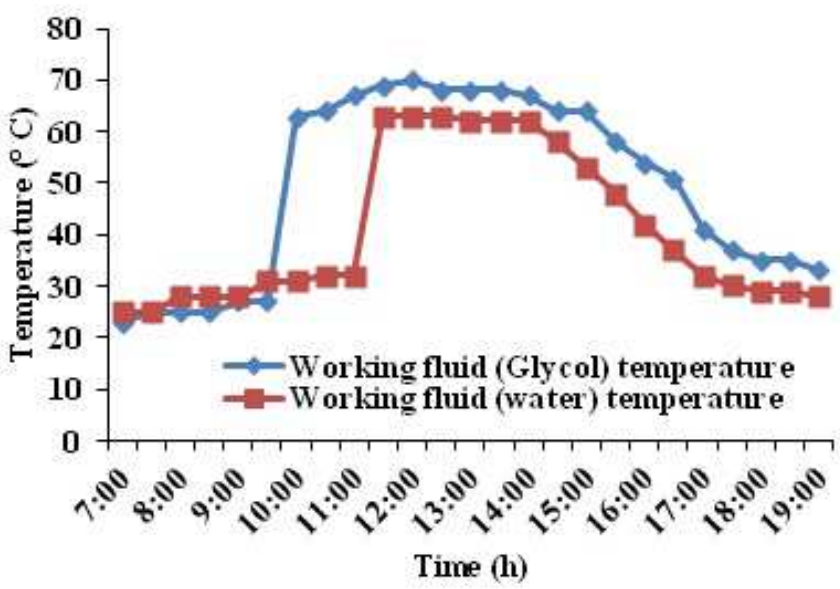

Figure 8. Variation of working fluid temperature

\subsection{Variation of Working Fluid Temperature}

Figure 8 describes the variations of surface temperature 
collector using water and glycol as a working fluid on a sunny day. Glycol and water temperature using as a working fluid were $23^{\circ} \mathrm{C}$ and $25^{\circ} \mathrm{C}$ respectively at $07: 00$ hrs. And gradually increased up to maximum of $70^{\circ} \mathrm{C}$ at 12:00 hrs in case of glycol and $63^{\circ} \mathrm{C}$ at $11: 30$ to $12: 00 \mathrm{hrs}$ in case of water on a sunny day and then decreases, in the evening at 07:00 hrs it was recorded as $33^{\circ} \mathrm{C}$ in case of glycol and $28^{\circ} \mathrm{C}$ in case of water.

\subsection{Efficiency of the System}

The solar water heater efficiency using water and ethylene glycol as a working fluid on a sunny day in the month of November, 2011, was $60 \%$ and $51.3 \%$ respectively.

\section{Conclusions}

Performance of a thermosyphon solar water heater equipped with a horizontal mantle storage tank in the mild winter of the North Eastern region of India was studied experimentally. The solar water heater has the capacity of 500 litre per day. The solar water heater has total collector area of $10.8 \mathrm{~m} 2$. The thermal performance of thermosyphon flat plate solar water heater was investigated on both sunny day and cloudy day. It is found that on a sunny day using water as a working fluid, the maximum storage tank temperature and hot water output temperature were $69^{\circ} \mathrm{C}$ and $62^{\circ} \mathrm{C}$ respectively at $13: 00-14: 00 \mathrm{hrs}$. The storage tank temperature and hot water output temperature was $75^{\circ} \mathrm{C}$ and $71^{\circ} \mathrm{C}$ respectively at $13: 00$ to $14: 00 \mathrm{hrs}$ on a sunny day using ethylene glycol as a working fluid. The solar collector efficiency using water and ethylene glycol as a working fluid on a sunny day in the month of November, 2011 , was $60 \%$ and $51.3 \%$ respectively.

\section{Acknowledgment}

The author thanks Dean, College of Agricultural Engineering and Post Harvest Technology, Ranipool, Gangtok, Sikkim for providing facilities and assisting in conducting research and development work.

\section{References}

[1] C. Ertekin, R. Kulcu, and F. Evrendilek. "Techno-Economic Analysis of Solar Water Heating Systems in Turkey", Sensors, Vol. 8, pp. 1252-1277, 2008.

[2] K. Lovegrove, and M. Dennis, "Solar thermal energy systems in Australia", International Journal of Environmental Studies, Vol. 63, Issue: 6, pp.791-802, 2006.

[3] O. B. Bukola, "Flow design and collector performance of a natural circulation solar water heater" Journal of Engineering and Applied Science, Vol. 1, Issue: 1, pp. 7-13, 2006.

[4] J. K. Paul, "Solar heating and cooling, recent advances", Noyes Data Corporation, New Jersey, 1979.

[5] N. M. Nahar, "Capital cost and economic viability of thermosyphonic solar water heaters manufactured from alternate materials in India", Renewable Energy, Vol. 26, pp. 623-63, 2002.

[6] B. Sitzmann, "Solar Water Heater with Thermosyphon Circulation", Appropriate Technology, Vol. 31, Issue: 1, pp. 66-70, 2004.

[7] D. J. Close, "The Performance of Solar Water Heaters with Natural Circulation", Solar Energy, Vol. 6, Issue: 1, pp. 33-40, 1962.

[8] J. Huang, S. Pu, W. Gao, and Y. Que, "Experimental investigation on thermal performance of thermosyphon flat-plate solar water heater with a mantle heat exchanger", Energy, Vol. 35, pp.3563-3568, 2010.

[9] S. R. Bello, and S. O. Odey, "Development of Hot Water Solar Oven for Low Temperature Thermal Processes", Leonardo Electronic Journal of Practices and Technologies, Vol. 14, pp.73-84, 2009.

[10] A. K. Soteris, "Solar Thermal Collectors and Applications", Progress in Energy and Combustion Science, Vol. 30, pp. 231-295, 2004.

[11] A. Manickavasagan, A. Sampathrajan, P. R. Manigandan, S. Manivannan, F. M. E. Emerald, R. Malarkodi, and S. Mangalam, "An experimental study on solar flat plate collector using an alternative working fluid", Pertanika Journal of Science \& Technology, Vol. 13, Issue 2, pp. 147-161, 2005. 